\title{
How Themistocles Zammit found Malta Fever (brucellosis) to be transmitted by the milk of goats
}

H V Wyatt

J R Soc Med 2005;98:451-454

One hundred years ago on 14 June 1905, Themistocles Zammit, a Maltese doctor, found that five out of six goats reacted to the blood test for brucellosis, then known as Mediterranean or Malta Fever. Vassallo has recounted the search for the source of the disease, ${ }^{1}$ but Zammit's previous experiments and how he came to test those goats have not been described.

The discovery that apparently healthy goats could be carriers of the disease has been termed 'one of the greatest advances ever made in the study of epidemiology'. ${ }^{2}$ It not only led in a few years to the elimination of the disease among British servicemen, but also revolutionized ideas about animal vectors of disease. Yet Zammit is all but forgotten. The discovery has been described as having arisen from an 'intuitive flash' that the goat might be susceptible, ${ }^{3}$ and was dismissed as an accident by Sir David Bruce - a judgment echoed in one of Bruce's obituaries: 'After months of hard and disappointing work, Dr Zammit, a Maltese colleague, happened to examine the blood of a goat'. ${ }^{5}$

The discovery was neither flash of intuition nor accident. After a year's work, the Mediterranean Fever Commission (MFC) had made little progress. With Zammit's intervention the problem was solved. ${ }^{6}$ That so many goats were naturally infected was so dramatic a finding that previous work was forgotten - especially since Zammit made few notes.

\section{CARUANA SCICLUNA AND ZAMMIT}

Nine months earlier, on 13 September 1904, G Caruana Scicluna, the senior medical officer of Malta and Zammit went to look for cases of malaria reported near Chadwick Lakes. Later that day, Major W H Horrocks of the MFC wrote to Bruce: 'Zammit... is ... attempting to infect goats by feeding'. ${ }^{7}$ Caruana Scicluna and Zammit returned to Chadwick Lake on 14 and 16 September $^{8}$ and on the 15 , the day they did not go, Zammit bought a 'white goat' and did the Malta Fever agglutination test on its blood, which

School of Philosophy, University of Leeds, Leeds LS2 9HD, UK Correspondence to: 1 Hollyshaw Terrace, Leeds LS15 7BG, UK

E-mail: nurhvw@leeds.ac.uk was negative. ${ }^{6}$ Why did Zammit suddenly start a new approach? I believe it was suggested by Caruana Scicluna.

The two doctors would have walked from the Health Ministry in Valletta to the Station for the 40 minute train journey to Mdina and continued by canopied carriage, a karozzini, to Chadwick Lakes. They would have been together for many hours: Zammit had recently been appointed to the MFC and they would have talked about Malta Fever. A few months earlier, on 8 June 1904, the Daily Malta Chronicle had reported that a family of five fell seriously ill after drinking goats' milk and that the goat was examined by the medical authorities. ${ }^{9}$ On the first page of his 1906 government pamphlet Caruana Scicluna wrote:

'In $1903 \ldots$...cases of fever had been observed among persons who lived in farms in which milch-goats supplying milk at Sliema were being kept... At the beginning of 1904, a Public Health Officer found that the blood of a goat...strongly reacted to Remittent Fever'. ${ }^{10}$

I suggest that Caruana Scicluna had told Zammit about the goat-herds and the positive goat.

At that point Zammit and Caruana Scicluna were probably speculating that just a few goats might be naturally infected, somewhere, among the 20000 goats on the island, with some unknown means of transfer to man - mosquitoes for instance. If only one goat in a hundred was positive would that be significant? The important observations on 14 June 1905 were, first, that goats were susceptible to infection with brucellosis and, second, that natural infection was very frequent.

Horrocks wrote to Bruce again on 23 September 1904 'Zammit is also trying to infect a goat by feeding it on Micrococcus Melitensis; if he succeeds we intend to repeat the experiment of feeding a monkey on its milk' ${ }^{11}$ I believe that Horrocks used 'we' as officer in charge of a subordinate, rather than as a colleague.

Zammit had fed his white goat agar cultures of M. melitensis on 18 September and 3 December 1904. The goat showed positive agglutination on 3 and 23 December and again on 29 April $1905 .{ }^{6}$ Zammit bought a 'red goat', 
also sero-negative, which was fed cultures on 3 and 5 December: it gave positive agglutinations on 23 December 1904 and 29 April 1905.6 He wrote that 'these two experiments led me to the belief that goats are susceptible to Malta fever, and that the disease may be spread to human beings by goats'. ${ }^{6}$ Bruce wrote: 'On 26th [June 1905] Major Horrocks ... also said that the milk of the goat fed by Dr. Zammit last September was still [my italics] crammed with M. melitensis'.12 A similar account, but without the 'still' was given in the minutes of the Sub-Committee in London. ${ }^{13}$ However, the letter itself only states that 'the serous-looking milk contained in the udder [was] crammed with M.M.'. ${ }^{14}$ That Zammit had previously found the bacteria in the milk before 14 June was confirmed by Professor J W H Eyre of Guy's Hospital, who had been to Malta in 1906 as head of the MFC. ${ }^{15}$ In his Milroy Lectures, Eyre singled out Zammit's work on goats:

'Zammit... had already attempted the infection of the most important animal in the Maltese domestic economy-viz., the goat-not only by the usual methods but, more important still, by feeding experiments carried out upon selected healthy animals. No constitutional effects were produced, but one month after administration of the growth from one agar tube culture of micrococcus Melitensis mixed with the food, specific agglutinins were discovered in the blood serum and steadily increased in amount as time went on. This experiment was repeated with similar results, and as months afterwards the serum reaction was found to be still present, although somewhat diminished in amount, a systematic examination of the blood, urine, and the milk was entered upon and Zammit was able to show that the specific micro-organism could be isolated from each and all of these fluids. ${ }^{15}$

Zammit, therefore, had already found bacteria in the milk, blood and urine of infected goats which showed no signs of disease.

\section{OTHER GOATS}

Zammit numbered his goats bought on 14 June 1-6, his white and red goats 7 and 8 , and 9 for a kid with no indication of when it had been bought. ${ }^{16} \mathrm{He}$ also recorded the agglutination reactions of goats 1 to 17 on 9 July. ${ }^{16}$ Goats 10-17 were presumably the eight he had bought from Mr Galdes of St Julian on 17 June.

Horrocks and Kennedy described experiments with monkeys and goats immediately after Zammit's discovery ${ }^{17}$ and they and Bruce listed the goats (Table 1). Kid 9 was
Table 1 Goats listed by Horrocks and Kennedy (Ref. 17) and tabled by Bruce who attributed the work to Horrocks and Kennedy (Ref. 18): Zammit not mentioned

\begin{tabular}{lllll}
\hline & $\begin{array}{l}\text { Interval } \\
\text { between } \\
\text { negative test } \\
\text { and experiment } \\
\text { (months) }\end{array}$ & $\begin{array}{l}\text { Experiment } \\
\text { started }\end{array}$ & $\begin{array}{l}\text { Thereafter } \\
\text { tested }\end{array}$ & Result \\
\hline 4 & 3 & 27 June & c. 25 March & Neg $^{\star}$ \\
8 & 2 & 29 June & c. 25 April & Neg \\
9 (kid) & 2 & 13 July & C. 14 May & Neg \\
12 & 1 & 31 July & 26 June & Neg \\
13 & $?$ & 13 July & $?$ & Neg \\
14 & $?$ & 20 July & $?$ & Neg \\
\hline
\end{tabular}

*Blood 'repeatedly examined... milk was removed on several occasions, and the deposit obtained by centrifugalisation plated: no signs of the specific micrococcus were observed'

clearly Zammit's, but their goats 4 and 8 cannot be Zammit's 4 and 8 because he had bought them on 14 June 1905 and September 1904, respectively. I suggest that Zammit had bought these three goats between March and May and had already tested the milk of their goat number 4 (Table 1), on the basis that his infection of two goats 'led me to the belief that goats are susceptible to Malta fever, and that the disease may be spread to human beings by goats' ${ }^{6}$ The obvious reason for buying a kid would be to feed it with milk from an infected lactating goat.

Surgeon E A Shaw RN had injected a goat in July 1904 and found infection with only a slight rise in temperature. He was, however, unable to find the bacteria in milk or urine. ${ }^{19}$ Thus, when Zammit bought six goats from two herds on 12 June 1905, the day that Bruce left Malta, ${ }^{12}$ seven goats and kids had been found seronegative. No wonder Zammit was greatly surprised ${ }^{20}$ that five of the six goats were positive. In retrospect, even more surprising is that with 'about $50 \%$ of the goats in Malta' positive, ${ }^{12}$ the first seven goats and kids they bought were negative, a chance of one in 128.

Brucellosis could also be transmitted sexually, ${ }^{21}$ by icecream and grog made with goats' milk, and perhaps, occasionally, by mosquitoes. In overcrowded naval ships, as in laboratory and abattoir outbreaks, infection may have been droplet-borne. ${ }^{22}$

\section{BRUCE, HORROCKS AND ZAMMIT}

Vassallo has shown how Bruce subtly gained credit to himself as the discoverer, ${ }^{1}$ but there were other controversies. A speaking tube connected Horrocks' laboratory with Zammit's on the floor below. Was it for Zammit to call Horrocks or for Horrocks to summon 
Zammit? On 23 September 1904 Horrocks wrote to Bruce 'In order to put in time, until I hear from you, I have put Zammit on to washing the walls and floors of infected areas. He is now doing a ward in the hospital'. ${ }^{11}$ I have found no mention of this in the results of the MFC and presume it was to isolate bacteria rather than cleansing. It was surely a task for a non-commissioned officer or orderly, not a doctor who was also a professor of chemistry: the MFC had at least one Royal Army Medical Corps orderly ${ }^{23}$ and the loan of an NCO. ${ }^{24}$ Major Horrocks was in charge, then Captain Kennedy, and, when he was away, Surgeon Shaw RN: it was a military operation with one civilian. (Maltese nobility and professionals were not allowed in the British club; after the Maltese had denied the British Governor entry to their own club, they were finally admitted to the British one.)

Horrocks had a close relationship with Bruce. After Zammit recovered the bacteria from the blood of a monkey infected by mosquitoes, Horrocks wrote 'I have taken some monkeys down to the Station Hospital in order to repeat the experiments free from Maltese influence!'25 Horrocks confirmed Zammit's results and published them in the MFC Reports Part I (1904, pp. 46-73). However, he went on 'The experiments... do not support the results obtained by Zammit'. Shaw wrote to Bruce 'It is I think, to be regretted that one member of the Commission [Horrocks] should in print attack the uncompleted work of another: between members of the same commission surely better done viva voce'. ${ }^{26}$

The first news of the goat discovery was delivered by Horrocks to Bruce on 20 June 1905: ${ }^{27}$ 'I bought a number of goats for Zammit and set him to examine the bloods before we commenced operations'. This sentence was underlined by Bruce who wrote in the margin (both in red ink) 'this is untrue, I put $\mathrm{T}$ on to this, see $\mathrm{T}$ 's letter 30 vi $05^{\prime}$. There is a similar red ink line in the margin and a red ink copy from Zammit's letter on Horrocks' letter to Bruce on 23 June. ${ }^{29}$ Bruce also underlined the 'I' in Horrocks' letter of 26 June where he wrote 'I have now found the $M$. melitensis in the milk of 5 goats....30 Zammit's account was confirmed by Shaw on 5 July. 'Zammit bought six more [goats] for experimental purposes and on examining...'31 (also underlined in red ink, as was 'I had' in Zammit's letter with a red line down the margin of the letter). I suggest that Horrocks was writing as a military officer about the work he was supervising, but the effect was to take all the credit.

On his visit to Malta in June 1904, Bruce wrote, 'I don't know how Zammit and Shaw will turn out as workers, but at present "I hae ma doutts", Shaw and Zammit were the ones who, despite the doubts of Bruce and the others, actually solved the problem of transmission of brucellosis.

\section{CONCLUSION}

Zammit not only made the initial discovery of naturally infected goats but also consistently pursued the subject of brucellosis by experiment, by epidemiology and by devising tests which were used by others - e.g. Zammit's test. He discovered that the milk of an inoculated goat contained the bacteria. To describe Zammit's discovery as simply an accident or a flash of intuition undervalues him and his work. Credit for this work is long overdue.

Acknowledgment I am grateful to the Wellcome Trust for a grant towards expenses.

\section{REFERENCES}

1 Vassallo DJ. The saga of brucellosis: controversy over credit for linking Malta fever with goats' milk. Lancet 1996;348:804-8

2 Tulloch WJ. Sir David Bruce. An appreciation. J R Army Med Corps 1955;101:81-90

3 Cassar P. Sir Themistocles Zammit and the Controversy on the Goat's Role in the Transmission of Brucellosis (Mediterranean Fever) 1909-1916. Valletta: Information Division-Kastilja, 1981

4 Bruce D. Recent researches into the epidemiology of Malta fever. $J R$ Army Med Corps 1907;8:225-35

5 Anon. Obituary: Major-General Sir David Bruce, K.C.B., F.R.S Nature 1932;129:84-6

6 Zammit T. A preliminary note on the susceptibility of goats to Malta Fever. Proc $R$ Soc 1905;76B:377-8. [Also J R Army Med Corps 1905;5:341-2, and shortened version in Reports of the MFC Part III; 1905:83]

7 Contemporary Medical Archives Collection (CMAC), Library of the Wellcome Institute for the History of Medicine. WTI/RST/G9/15. Letter Horrocks to Bruce 13 September 1904

8 Zammit T, Caruana Scicluna G. Intermittent fever in Malta. BMJ 1905; $1: 711$

9 Caruana Scicluna G. The Milch-goat as a Factor in the Propagation of Mediterranean Fever (published in English, Italian and Maltese). Malta: Government Printing, May 1906

10 Anon. Milk poisoning. Daily Malta Chronicle 8 June 1904

11 CMAC. WTI/RST/G9/17. Letter Horrocks to Bruce 23 September 1904

12 Bruce D. Introduction. Reports of the MFC Part III; 1905:3-4

13 Minutes of the MFC, the Royal Society Sub-committee. Royal Society Archives, London. CMB 50-52. Also CMAC. WTI/RST/ $\mathrm{G} 8 / 2$

14 CMAC. WTI/RST/G9/102. Letter Horrocks to Bruce 26 June 1905

15 Eyre JWH. The Milroy Lectures on Melitensis septicaemia (Malta or Mediterranean Fever). Lancet 1908;i:1677-82, 1747-52, $1826-32$

16 Zammit T. Lazzaretto Station Notes. Zammit's notebook now at the Ministry of Health, Valletta, Malta GC

17 Horrocks WH, Kennedy JC. Goats as a means of dissemination of Mediterranean fever. Reports of the MFC Part IV; 1906:37-69

18 Bruce D. Malta fever. J R Army Med Corps 1906;6:330-52 
J O U R N A OF T HE ROYA L SOCIETY OF MEDICINE Volume 98 October 2005

19 Wyatt HV. Royal Navy surgeons and the transmission of brucellosis by goats' milk. J R N Med Service 1999;85:112-17

20 Horrocks WH. Preliminary note on goats as a means of propagation of Mediterranean fever. Reports of the MFC Pt III 1905: 84-90

21 Wyatt HV. Brucella melitensis can be transmitted sexually. Lancet 1996;348:615

22 Dudley SF. Some lessons of the distribution of infectious diseases in the Royal Navy. Lecture III. The history of undulant fever in the Royal Navy. Lancet 1931;i:683-91

23 CMAC. WTI/RST/G9/102. Letter Horrocks to Bruce 26 June 1905

24 CMAC. WTI/RST/G9/148. Letter Horrocks to Bruce 11 December 1905
25 CMAC. WTI/RST/G9/13. Letter Horrocks to Bruce 5 September 1904

26 CMAC. WTI/RST/G9/45. Letter Shaw to Bruce 26 November 1904

27 CMAC. WTI/RST/G9/101. Letter Horrocks to Bruce on 20 June 1905

28 CMAC. WTI/RST/G9/103. Letter Zammit to Bruce on 30 June 1905

29 CMAC. WTI/RST/G9/97. Letter Horrocks to Bruce on 23 June 1905

30 CMAC. WTI/RST/G9/102. Letter Horrocks to Bruce on 26 June 1905

31 CMAC. WTI/RST/G9/104. Letter Shaw to Bruce on 5 July 1905

32 Royal Society Archives MC 4109. Letter Bruce to the Secretary of the Royal Society 16 June 1904 